\title{
Selective deposition response to aeolian-fluvial sediment supply in the desert braided channel of the upper Yellow River, China
}

\author{
H. Wang ${ }^{1, \mathrm{a}}$, X. Jia ${ }^{1}$, Y. Li ${ }^{1}$, and W. Peng ${ }^{1}$ \\ ${ }^{1}$ Key Laboratory of Desert and Desertification, Cold and Arid Regions Environmental and Engineering Institute, \\ Chinese Academy of Sciences, Gansu Province 730000, China \\ ${ }^{a}$ now at: Cold and Arid Regions Environmental and Engineering Research Institute, Chinese Academy of Sciences, 260 \\ Donggang West Road, Lanzhou, Gansu Province, 730000, China \\ Correspondence to: H. Wang (hbwang@lzb.ac.cn)
}

Received: 23 December 2014 - Published in Nat. Hazards Earth Syst. Sci. Discuss.: 10 February 2015

Revised: 7 July 2015 - Accepted: 19 August 2015 - Published: 2 September 2015

\begin{abstract}
Rivers flow across aeolian dunes and develop braided stream channels. Both aeolian and fluvial sediment supplies regulate sediment transport and deposition in such cross-dune braided rivers. Here we show a significant selective deposition in response to both aeolian and fluvial sediment supplies in the Ulan Buh desert braided channel. The Ulan Buh desert is the main coarse sediment source for this desert braided channel, and the mean percentage of the coarser $(>0.08 \mathrm{~mm})$ grains on the aeolian dunes surface is $95.34 \%$. The lateral selective deposition process is developed by the interaction between the flows and the aeolian-fluvial sediment supplies, causing the coarser sediments $(>0.08 \mathrm{~mm})$ from aeolian sand supply and bank erosion to accumulate in the channel centre and the finer fluvial sediments $(<0.08 \mathrm{~mm})$ to be deposited on the bar and floodplain surfaces, forming a coarser-grained thalweg bed bounded by finer-grained floodplain surfaces. This lateral selective deposition reduces the downstream sediment transport and is a primary reason for the formation of an "aboveground" river in the braided reach of the upper Yellow River in response to aeolian and fluvial sediment supplies.
\end{abstract}

\section{Introduction}

In nature, some rivers flow across active dune fields and become shifted and braided, developing many channel bars and large-area floodplains (Smith and Smith, 1984; Ta et al., 2008). Smith and Smith (1984) indicated that abrupt addition of aeolian sands to rivers can lead to a 40 -fold increase in bed load, a 5-fold increase in width and a 10-fold increase in width / depth ratio in a small desert river (William River, Canada), and is a primary mechanism for the development of such a braided stream channel. Actually, large cross-dune rivers are also fed by high rates of upstream suspended sediment supplies (Ta et al., 2008, 2011). However, it is still less clear how these two aeolian and fluvial sediment supplies can be regulated to influence sediment transport and deposition in such a cross-dune desert river.

In gravel-bed rivers, the channel bed is composed of two components: sand $(<2 \mathrm{~mm})$ and gravel $(>2 \mathrm{~mm})$. Wilcock (1998) indicated that the sand supply $(<2 \mathrm{~mm})$ has a great impact on gravel transport and size change of bed sediment in gravel-bed rivers. If the sand supply is decreased or increased from upstream, the channel bed of gravel-bed rivers will become coarser or finer, respectively (Dietrich and Smith, 1983; Ferguson et al., 1989, 1996; Parker and Sutherland, 1990; Hoey and Ferguson, 1994; Pizzuto, 1995; Wilcock, 1998; Gasparini et al., 1999; Lisle et al., 2000; Wilcock and Kenworthy, 2002; Singer, 2008). Since crossdune rivers with a low gradient are sand-bed rivers, their bed sediment sizes are actually less than $2 \mathrm{~mm}$ and are in a state of fully mobilized transport, which makes differences in the threshold of motion between coarser and finer grains relatively unimportant and give all sizes of sediments equal mobility (Frings, 2008). Church (2006) indicated that bedloads are relatively coarse and make up the beds and lower banks of the river channel, but suspended loads are finer and may be an important constituent of the upper banks. Ta et al. (2011) also showed that mid-channel bars are distinguished with a finer 


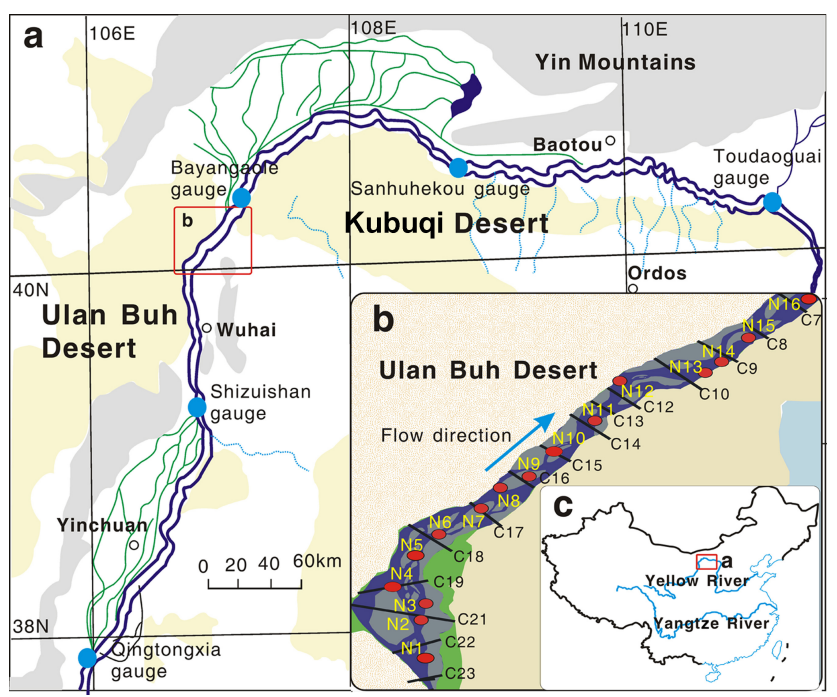

Figure 1. Schematic illustration of the Ulan Buh desert braided channel of the Yellow River, China. (a) The Yellow River flows through the Ulan Buh Desert and the Kubuqi Desert, the braided channel is from Wuhai to Sanhuhekou, and the meandering channel is from Sanhuhekou to Toudaoguai; (b) the studied desert channel; (c) the Yellow River and Yangtze River in China.

surface layer $(<0.08 \mathrm{~mm})$ developing on a subsurface layer $(>0.08 \mathrm{~mm})$ in the sand-bed braided and meandering rivers in the upper Yellow River. These results suggest that although the sand-bed channel shows an equal threshold of motion between coarser and finer grains, it can actually transport and deposit sediments selectively rather than uniformly (Frings, 2008; Wright and Parker, 2005; Ta et al., 2011). Because aeolian sands generally are coarser than river-suspended sediments in grain size (Ta et al., 2011), we propose that aeolian and fluvial sediment supplies may be transported as bedloads and suspended loads, respectively, leading to selective deposition in different zones to form size segregation in braided channels. However, until now, there have been no field and flume data to support this hypothesis. Nonetheless, understanding the size segregation mechanism is important for predicting sediment transport and deposition and channel change in braided channels.

Here we present field evidence of selective deposition in the Ulan Buh desert braided channel of the Yellow River, China, which responds to finer $(<0.08 \mathrm{~mm})$ suspended sediment supply from the upstream and coarser $(>0.08 \mathrm{~mm})$ aeolian sand supply from the Ulan Buh desert (Ta et al., 2011). Our main objective is to clarify the lateral selective deposition mechanism in response to aeolian and fluvial sediment supplies in a large, low-gradient, and sand-bed braided river, and to shed some light on what the effect of this selective deposition is on the channel morphologies in braided rivers.

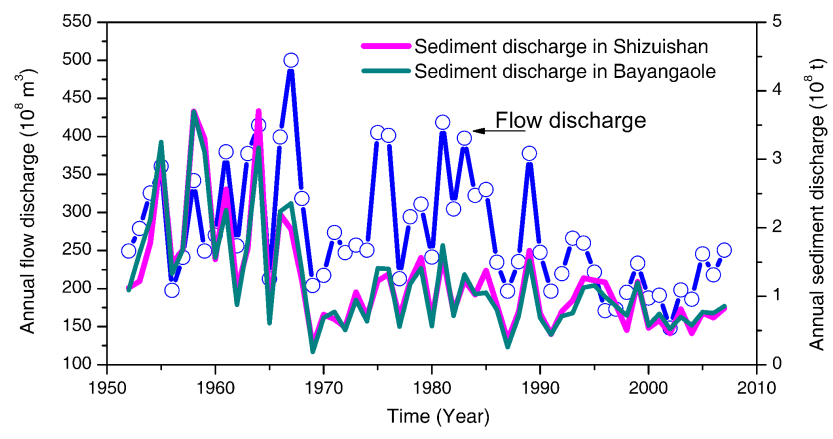

Figure 2. Changes in annual flow and sediment discharges monitored in the Shizuishan gauge and the Bayangaole gauge (data come from the YRCC) from 1955 to 2007 in the Yellow River.

\section{Study area}

To clarify the size segregation mechanism in response to the aeolian and fluvial sediment supply, we chose the $60 \mathrm{~km}$ long section of the Ulan Buh desert channel of the Yellow River, China (Fig. 1). This desert channel is a braided channel with an average gradient of 0.00028 and has no confluence with tributaries. According to long-term observations (data are from 1955 to 2007) by the Yellow River Conservation Commission (YRCC), the finer sediment supply $(<0.08 \mathrm{~mm})$ from the upstream is about $(1.23 \pm 0.8) \times 10^{8} \mathrm{tyr}^{-1}$ but about $(1.21 \pm 0.8) \times 10^{8} \mathrm{tyr}^{-1}$ of the suspended sediment is transported out of the desert channel (Fig. 2). The results of variance analysis showed that there was no significant variation in the finer sediment load between two gauges $(P>0.05)$.

The Ulan Buh desert is located in the northwest of the Yellow River and topography is gradually tilted from northwest to southeast. The dune heights are $7-20 \mathrm{~m}$ and the mean percentage of the coarser $(>0.08 \mathrm{~mm})$ and finer $(<0.08 \mathrm{~mm})$ grains on the aeolian dunes surface from the Ulan Buh desert are 95.34 and $4.66 \%$, respectively. Under the $\mathrm{W}$ and NWdominant strong winds in the region, the strong windblown sand/dust activity transports a large amount of the coarse sands entering the desert channel and causes dunes to move forward. Ta et al. (2008) estimated that the coarser sediment $(>0.08 \mathrm{~mm}$ ) input from the local Ulan Buh desert region is about $0.2 \times 10^{8} \mathrm{t} \mathrm{yr}^{-1}$ on long-term average. Based on coastal dunes mobile monitoring results, He et al. (2012) suggested that the dunes move forward a distance of $8.19 \mathrm{~m} \mathrm{yr}^{-1}$ towards the river channel, mainly occurring in March to May. Thus, the Ulan Buh desert is the main coarse sediment source for the study area of this desert channel.

Due to the increase of coarse sediment loads and the reduction of annual flow discharge upstream, this desert channel has shown aggradation and a significant decrease in bankfull discharge during the last 30 years (Wu and $\mathrm{Li}, 2011)$ and is characterized by lateral shift, leading to a wide distribution of river bars and floodplains (Ta et al., 2008). Therefore, 
this desert channel provides an unusual opportunity to study size segregation in response to the aeolian and fluvial sediment supply and the development of large-area floodplains in large braided rivers.

\section{Methods}

In the Ulan Buh desert reach, the Yellow River Engineering and Management Bureau of the Inner Mongolia Autonomous Region (YREMB) installed 23 cross sections and surveyed them in April and October every year for about 45 years (1966-present). Along these cross sections, sediment samples on the main channel beds and bars or floodplain surfaces have also been collected and their grain size distributions have been analysed. This study provided long-term data on changes in the channel lateral shift and the grain size of bed sediments. However, there have been no reports on the lateral size segregation in response to the aeolian and fluvial sediment supplies and the related lateral channel shifts. Here we choose 12 wider cross sections (C8, C10, C12, C14C22) in the desert channel (Fig. 1b), which is fed by aeolian and fluvial sediment supply and shows high rates of lateral channel shifts. We complied 45-year (1966-2011) monitoring data of these 12 cross profiles and their related grain size distributions of bed sediments (C15, C17, C19, and C21 were not included because their bed sediments were not collected) from the YREMB to study the lateral size segregation of the channel bed sediments and the lateral channel shift in the Ulan Buh desert braided reach. We chose 16 channel bars (N1-N16) in the desert channel and took 3 m-deep core sediment samples from them (Fig. 1b). These sediment cores were cut and separated to obtain $4 \mathrm{~cm}$ column samples, and dried and sieved to analyse the vertical size distributions. We collected suspended sediment samples at three vertical profiles in the main channel, with a $30 \mathrm{~cm}$ height interval at the $1.5 \mathrm{~m}$-thick near-bed layer, and a $50 \mathrm{~cm}$ height interval at the upper layer along the cross section in the Sanhuhekou gauge station (Fig. 1a) to analyse the vertical size distribution of suspended sediments. These data were used to analyse the selective transport of all sizes of transported sediments during the passage of a flood. We also choose 11 high-flow floods $\left(>3500 \mathrm{~m}^{3} \mathrm{~s}^{-1}\right.$ ) from 1955 to 2012 (monitored by Shizuishan and Bayangaole gauges), which provide strong evidence to confirm that the suspended sediment loads in the desert braided channel should be attributed to upstream sediment supplies rather than bed coarser sediments from aeolian supplies or bank erosions.

\section{Results}

The long-term monitoring data of 12 wider cross sections in the Ulan Buh desert reach of the Yellow River indicated that the main channel beds show coarser-grained sediments $(>0.08 \mathrm{~mm})$ but the bar or floodplain surfaces show finer-

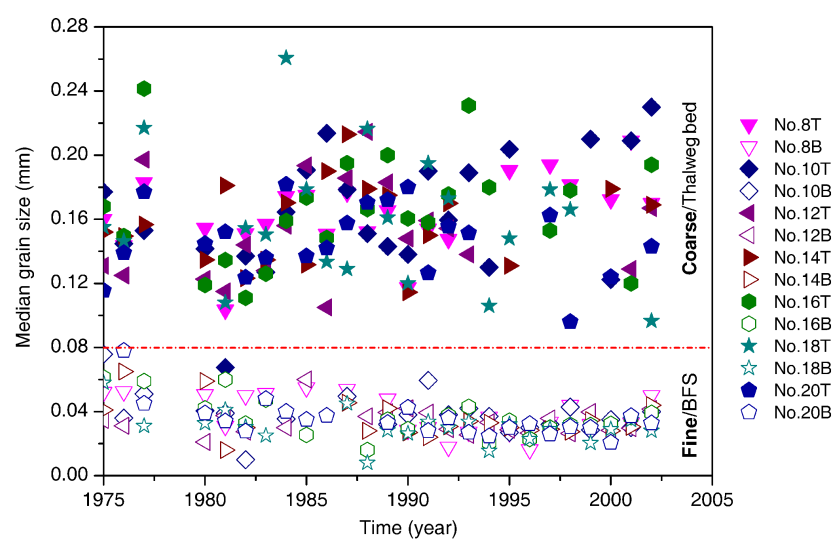

Figure 3. The median sizes of the thalweg bed sediments and the bar or floodplain surface sediments (BFS) in the Ulan Buh desert braided channel from 1975 to 2005 .

grained sediments $(<0.08 \mathrm{~mm})$ (Fig. 3), suggesting a lateral size selective deposition in response to coarser aeolian $(>0.08 \mathrm{~mm})$ and finer fluvial $(<0.08 \mathrm{~mm})$ sediment supplies. This lateral sediment deposition is also found to be accompanied by vertical size selective deposition, leading to finer surface layers $(<0.08 \mathrm{~mm})$ developing over coarser subsurface layers $(>0.08 \mathrm{~mm})$ in the 16 channel bars in the desert braided channel (Fig. 4). These finer surface layers are thinner $(50-120 \mathrm{~cm})$ and are sometimes lacking; for example, there are no finer surface layers in the five channel bars (N3, N8, N9, N13, and N14) in the braided channel. Our observations also indicated that this selective deposition is primarily accommodated through selective transport, during which the $<0.08 \mathrm{~mm}$ size fraction is found to be transported as suspended loads, but the $>0.08 \mathrm{~mm}$ size fraction is transported primarily as bedloads (Fig. 5) at flow discharge conditions $\left(1000-3000 \mathrm{~m}^{3} \mathrm{~s}^{-1}\right)$ (Fig. 6). These results support our hypothesis and indicate that the aeolian and fluvial sediment supplies cannot be mixed effectively in the braided channel and therefore tend to be primarily transported separately as bedloads and suspended loads, respectively, leading to selective deposition in different zones and forming a coarsegrained main channel bed bounded by fine-grained bar or floodplain surfaces.

This lateral size segregation develops through the lateral channel shift in the braided channel. When the channel migrates towards the aeolian sand-covered bank(ACB), the aeolian dunes are eroded and side bars develop on the opposite banks, or mid-channel bars develop between the channels; but if the channel moves leaving from the ACB, the sand bars form between the main channel and the $\mathrm{ACB}$, which in turn block the wind-blown sands entering the stream channel (Fig. 7). This lateral channel shift causes the coarse aeolian sands to accumulate around the channel centre and drives the suspended sediments to be deposited on the surfaces of sand bars. During this lateral shift, the main thalweg bed rose 

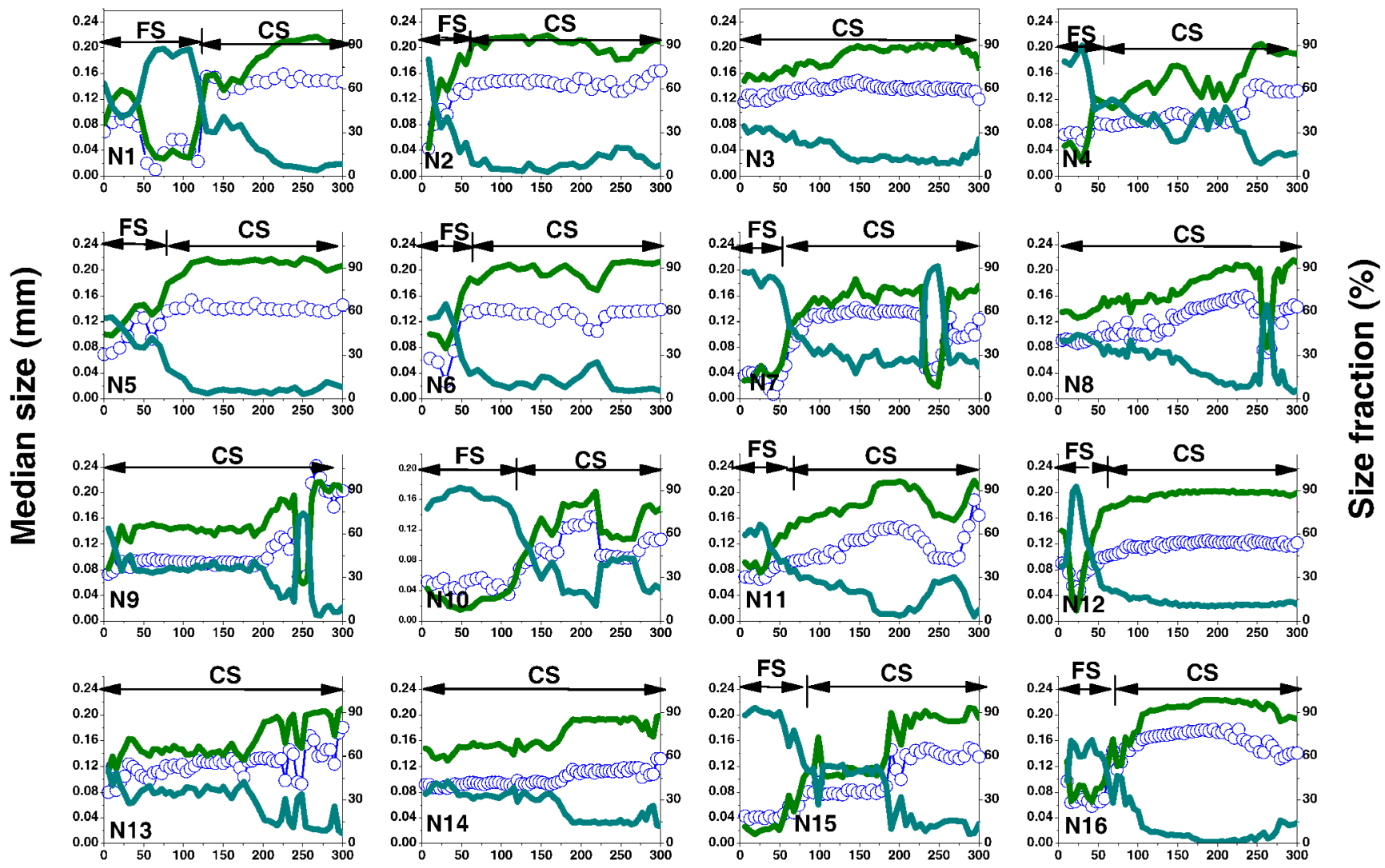

\section{Depth (cm)}

Figure 4. Vertical distributions of portions of the two-fraction sediments $(>0.08 \mathrm{~mm}$ and $<0.08 \mathrm{~mm})$ and the related median sizes in 16 sediment cores (N1-N16, see in Fig. 1b) in the channel bars in the Ulan Buh desert braided channel. Olive-green lines depict curves of the portions of the $>0.08 \mathrm{~mm}$ sediments, dark cyan lines depict curves of the portions of the $<0.08 \mathrm{~mm}$ sediments and blue circles depict curves of the median sizes of sediments.

about $1.33 \mathrm{~m}$ on average in the range of 0.169 to $2.295 \mathrm{~m}$ during the forty-five years (Fig. 8).

Although the channel shows high rates of lateral shifts in response to high-rate flow discharges, the suspended sediment concentrations in the desert reach primarily vary in response to sediment supplies from upstream but were surprisingly low (6.48-6.88) in response to the flow discharge peaks near $5000 \mathrm{~m}^{3} \mathrm{~s}^{-1}$ (Figs. 9 and 10). Linear fitting using a least squares method indicates that when the flow discharge ranges from 3500 to $5210 \mathrm{~m}^{3} \mathrm{~s}^{-1}$, the suspended sediment load in the desert braided channel can actually be regulated by the upstream supplies rather than the flow discharges (Fig. 11). This result indicates that it may be hard for the $>0.08 \mathrm{~mm}$ bed sediments to be suspended from the bed as suspended sediment loads at such a low gradient $(0.00025)$ and sand-bed river during the passage of a flood. The result further indicates that the portion of the finer $(<0.08 \mathrm{~mm})$ sediments from the sand bar or floodplain can be transported downstream as suspended sediment loads, which make the suspended sediment load at the Bayangaole gauging station greater than that at Shizuishan gauging station. Although the mean percentage of the finer $(<0.08 \mathrm{~mm})$ grains from the sand bar or floodplain are $30.71 \%$, only some of the finer $(<0.08 \mathrm{~mm})$ surface sediments can be transported downstream during the flood events. Due to the higher transport capacity of the river for the finer $(<0.08 \mathrm{~mm})$ sediments, the beginning of the flow discharge increases in a flood event, and the limited finer $(<0.08 \mathrm{~mm})$ surface sediments form a higher peak in suspended sediment concentrations. With the flow discharge continuously increasing and the insufficient supply of fine sediment particles, the peak value for the discharge and sediment differed in time.

\section{Discussions and conclusions}

Our results suggest that the significant lateral size segregation can be produced in response to aeolian and fluvial sediment supplies in our studied braided channel. Aeolian sand supply and bank erosion provide enough available bedloads which contribute to the primary bed sediments and con- 


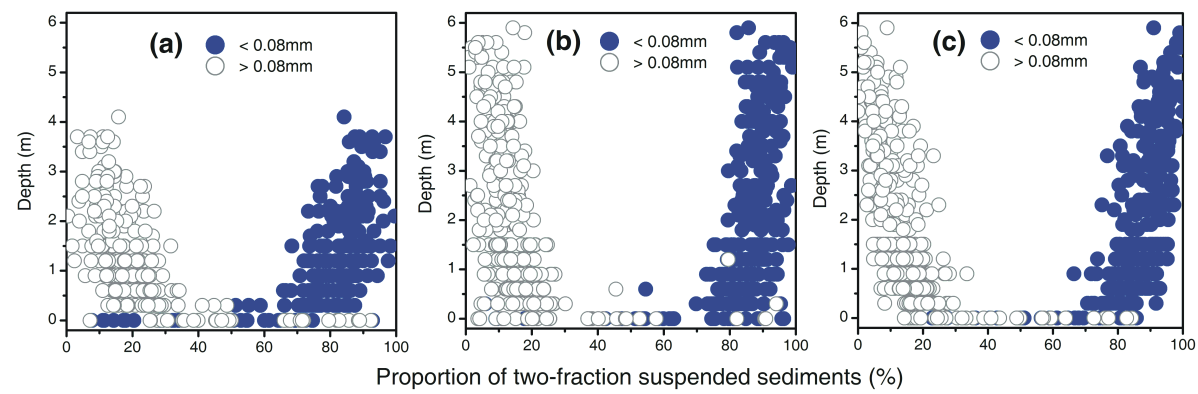

Figure 5. Vertical profiles of proportions of the two-fraction sediments $(>0.08 \mathrm{~mm}$ and $<0.08 \mathrm{~mm})$ in the cross section of the Sanhuhekou gauge during the passage of a flood with a flow discharge from 1000 to $3200 \mathrm{~m}^{3} \mathrm{~s}^{-1}$ in 2012 . (a) $540 \mathrm{~m}$ distance from the starting point of the cross section in the left bank, (b) $620 \mathrm{~m}$ distance from the starting point of the cross section in the left bank, (c) $700 \mathrm{~m}$ distance from the starting point of the cross section in the left bank.

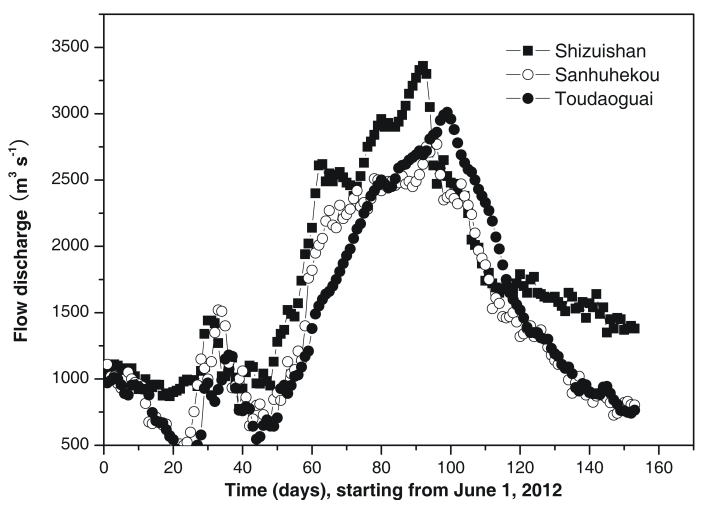

Figure 6. Flow discharges monitored in three gauges (Shizuishan, Sanhuhekou and Toudaoguai) in the braided and meandering channels during the passage of a flood in 2012 .

trol the development of the braided channel. Although fluvial sediment supplies from the upstream are larger in quantity than the aeolian sand supplies, they actually are wash loads; this shows the well-known phenomenon of "the more it come, the more it goes" (Wu et al., 2008), and therefore cannot be deposited in the main channel bed but can be deposited in slack water on bar tops and overbank during floods (Church, 2006). Since the braided channel is unstable and shifts laterally, the bar or floodplain tends to be eroded and its finer surface sediments can be transported downstream as suspended loads, but the coarser subsurface sediments show local erosion and deposition processes and thereby should be of major importance in determining braided channel morphology (Church, 2006).

Some studies have shown that the helical secondary flow (HSF) develops by the skewing of cross-stream vorticity into a long-stream direction, carrying faster surface water towards the outer bank and slower bed water towards the inner bank in a braided or meandering channel (Dietrich and Smith, 1983; Thorne et al., 1985). The HSF erodes the outer bank and fills the inner bank, leading to an asymmetrical cross section and a lateral channel shift. Because the cross profile of the stream channel is roughly a parabola and because the downslope gravity component of sand grains is a body force and the fluid drag component is a surface force, increased grain size of sediments caused an increase in the downslope gravity component of grains greater than in the fluid drag and accelerated the accumulation of coarse sediments in the channel centre (Wilson, 1973).

Although the HSF was not examined in our studies, it plays an essential role in the development of the lateral size segregation in response to aeolian and fluvial sediment supplies. As wind-blown sands move downwind and meet the stream channel, the wind cannot carry sands continuously in the water, and therefore tend to deposit aeolian sands on channel sides to form aeolian dunes in the stream banks. In these conditions, if the HSF drives the channel towards the aeolian sand-covered bank, the aeolian dunes are eroded and the aeolian sands can creep along the outer bed slope towards the channel centre under the influence of the fluid drag and the gravity component; but on the inner bed slope of the opposite bank, the fluid drag and the gravity component are in a different direction and their balance will determine and separate the coarser and finer sediment deposition zones, causing the coarser sediments to accumulate in the channel bottom and the finer suspended sediments to deposit on the bar platform surfaces. However, if the HSF drives the main channel away from the aeolian sand-covered bank, the suspended sediments in turn tend to be transported towards the aeolian sand-covered bank and to be deposited to form new bars or to expand old floodplains. This expanded floodplain thereby separates the main channel and the aeolian sand-covered bank and blocks wind-blown sands entering the main channel. This channel shifts continuously back and forth, causing coarser aeolian sands to accumulate in the channel centre and causing finer sediments to be deposited on the bar or floodplain surfaces on the channel sides; this is a primary mechanism for the long-term size segregation and channel change in the braided channel. 


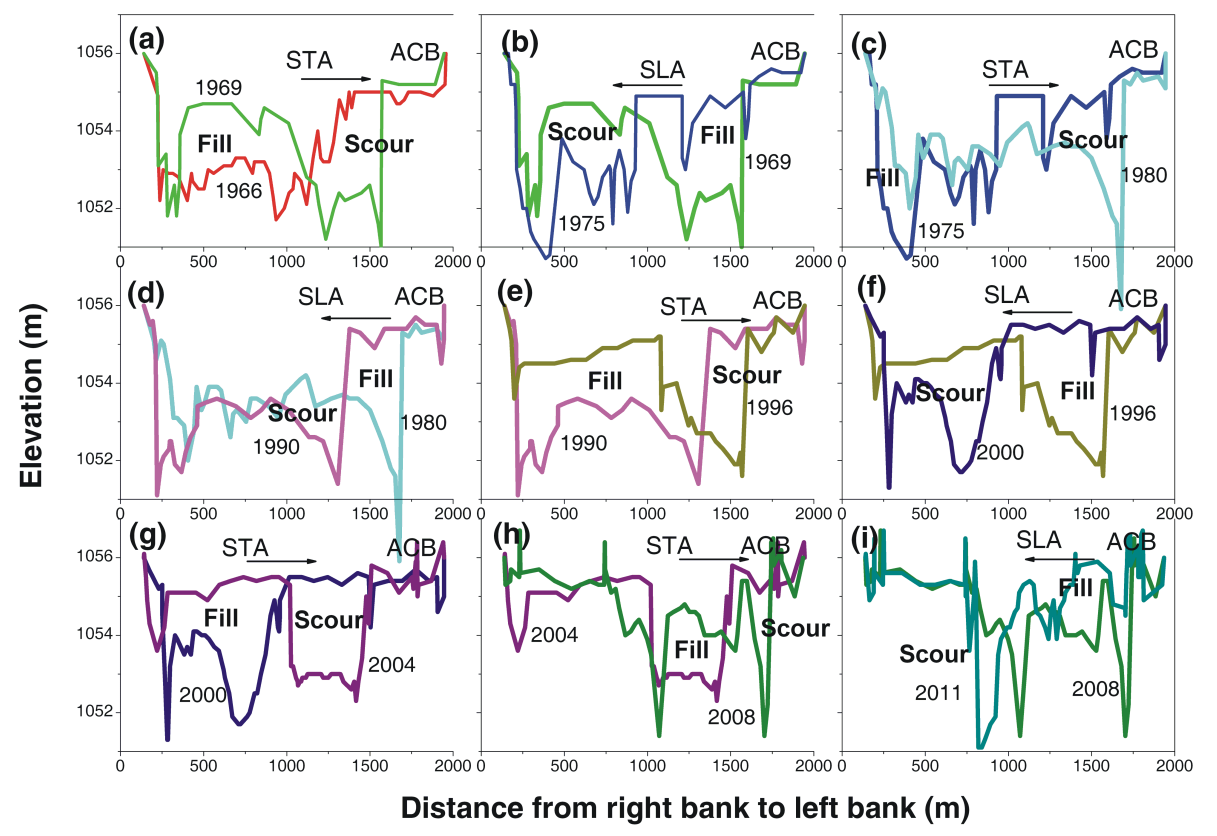

Figure 7. Changes of the cross section of C8 from 1966 to 2011. ACB is the aeolian sand-covered bank, STA is the channel shift towards the ACB and SLA is the channel shift leaving from the ACB. (a), (c), (e), (g) and (h) indicate that when the channel shifts toward the ACB, the sand dunes are eroded and the aeolian sands are transported towards the channel centre and the point bars are then formed on the opposite bank. (b), (d), (f), and (i) show that as the channel moves away from the ACB, the point bars are formed between the main channel and the $\mathrm{ACB}$, which in turn block wind-blown sand entering into the channel.

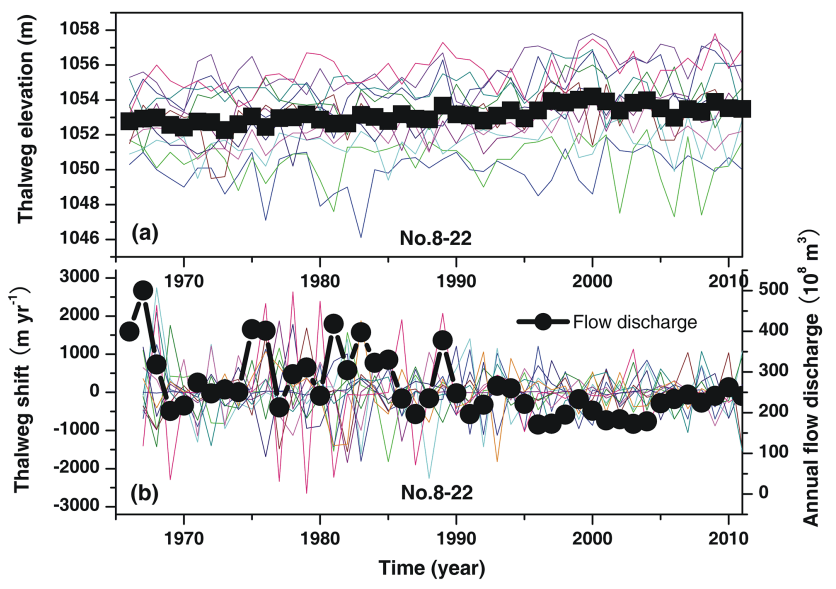

Figure 8. Lateral channel shifts (b) and the rising thalweg beds (a) monitored from 1965 to 2012.

Our results suggest that the braided channel is stronger in the lateral size segregation than in the longitudinal size segregation, which is supported by evidence that the cross profile adjusts to changing conditions much more rapidly than the long profile, as suggested by Wilson (1973). Because aeolian sand supply originates from river banks, which differs from fluvial sediment supply through stream channels, the traditional downstream fining of bed sediments shows no significance in the aeolian sand-fed braided channel. Frings (2008) argued that the size segregation primarily resulted from the presence of suspended load transport in combination with the effects of dune and bend sorting in large sand-bedded rivers, making selective transport and deposition of different size sediments and producing downstream fining of bed sediments. Although he mainly focused on the longitudinal size segregation in large sand-bedded rivers, he also realized the importance of sediment addition and extraction, and the influence of changes of overbank sedimentation on the bed sizes in large sand-bedded rivers.

We propose that in rivers which flow through aeolian dunes, increased bedload supply, as a result of increased aeolian processes or accelerated bank erosions, may cause the channel to be filled with coarser sediments and consequently become a shallow and shifting braided channel. If accelerated erosion leads to increased finer sediment supply from upstream, the HSF will respond by transporting the suspended sediment towards the stream sides and by accelerating the deposition of the finer sediments on the point bar or floodplain surfaces. Since the HSF causes the lateral selective deposition and consequently reduces downstream sediment transport, the braided channel will show aggrading in response to both aeolian and fluvial sediment supplies. This mechanism may explain the formation of the "above-ground river" in the braided reach of the upper Yellow River (Ta et al., 2011). Because the HSF may regulate the lateral size segregation in 

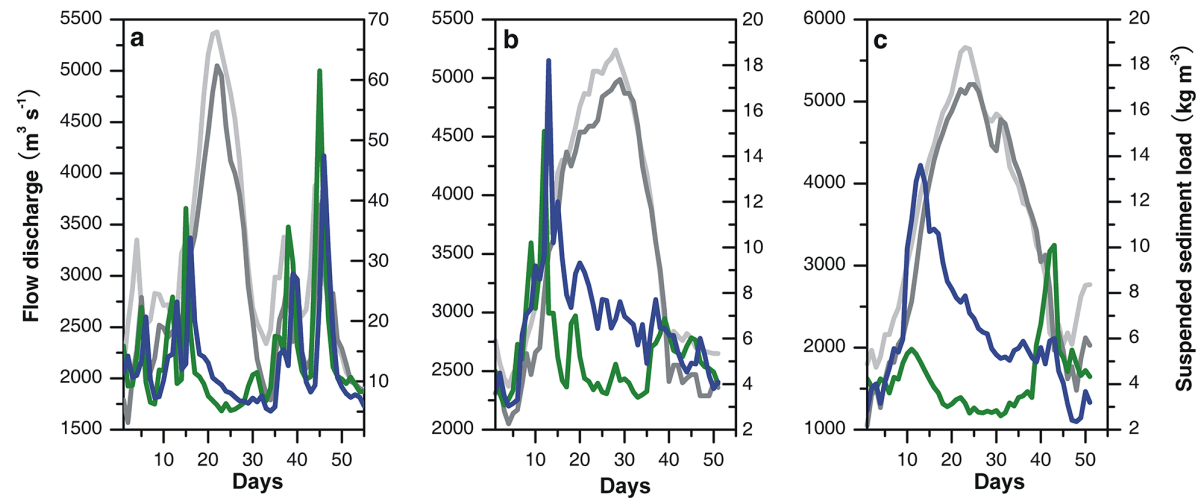

Figure 9. Daily suspended sediment loads and flow discharges of three flow peaks $\left(>4000 \mathrm{~m}^{3} \mathrm{~s}^{-1}\right)$ flowing through the Ulan Buh desert braided channel. (a) $5050 \mathrm{~m}^{3} \mathrm{~s}^{-1}$ flow discharge peak on 31 July 1964; (b) $4990 \mathrm{~m}^{3} \mathrm{~s}^{-1}$ flow discharge peak on 16 September 1967 ; (c) $5210 \mathrm{~m}^{3} \mathrm{~s}^{-1}$ flow discharge peak on 21 September 1981. Light grey and grey lines depict curves of flow discharges monitored in Shizuishan and Bayangaole gauges, respectively; olive-green and blue lines depict curves of suspended sediment loads monitored in Shizuishan and Bayangaole gauges, respectively.

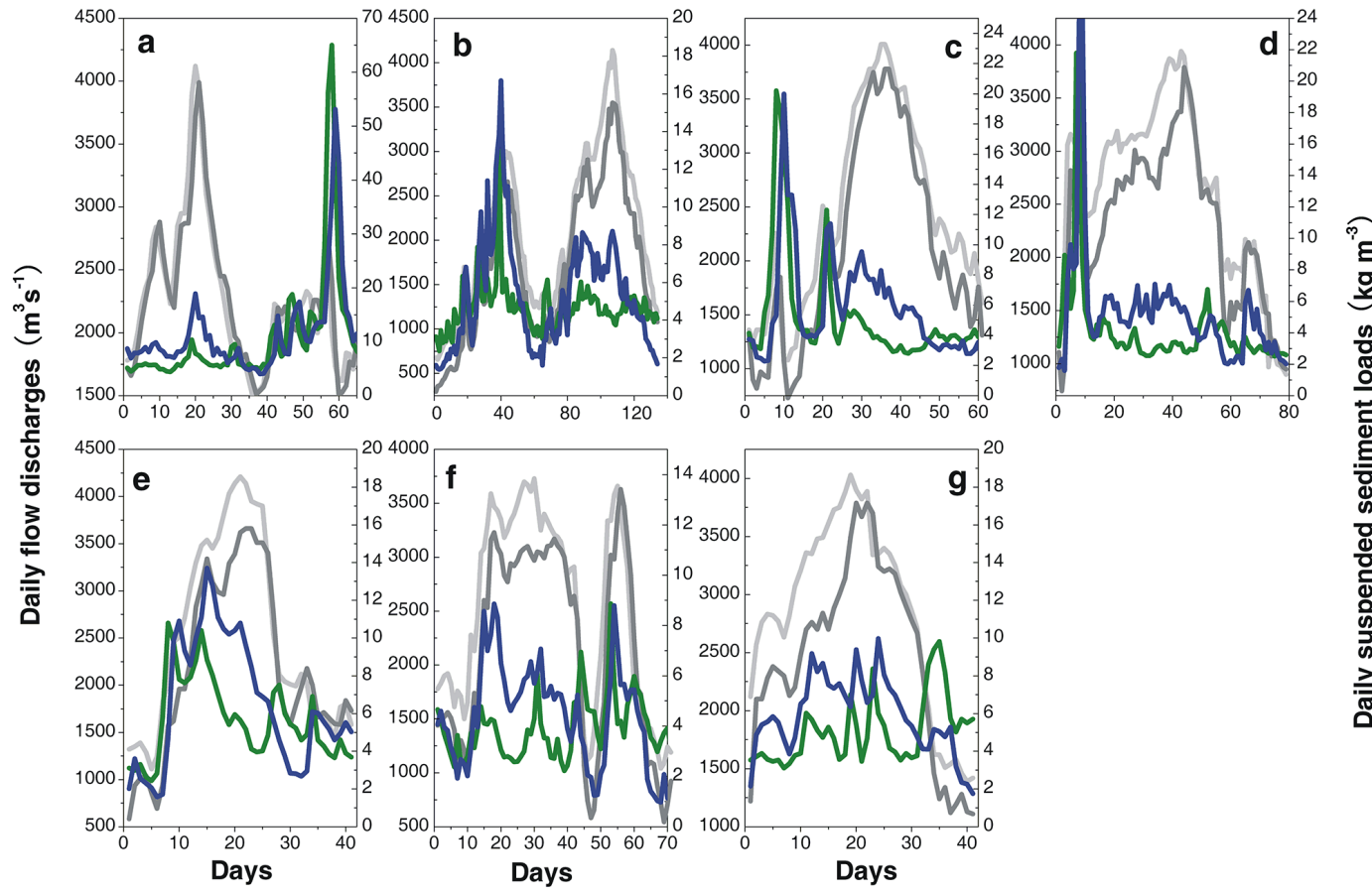

Figure 10. Daily suspended sediment loads and flow discharges of eight flow peaks (3500-4000 $\mathrm{m}^{3} \mathrm{~s}^{-1}$ ) flowing through the Ulan Buh desert braided channel. (a) $3990 \mathrm{~m}^{3} \mathrm{~s}^{-1}$ flow discharge peak on 20 July 1955; (b) $3550 \mathrm{~m}^{3} \mathrm{~s}^{-1}$ flow discharge peak on 4 October 1963 ; (c) $3780 \mathrm{~m}^{3} \mathrm{~s}^{-1}$ flow discharge peak on 23 September 1968; (d) $3790 \mathrm{~m}^{3} \mathrm{~s}^{-1}$ flow discharge peak on 13 September 1976 ; (e) $3660 \mathrm{~m}^{3} \mathrm{~s}^{-1}$ flow discharge peak on 19 September 1978; (f) $3630 \mathrm{~m}^{3} \mathrm{~s}^{-1}$ flow discharge peak on 24 August 1983; (g) $3790 \mathrm{~m}^{3} \mathrm{~s}^{-1}$ flow discharge peak on 5 August 1984. Light grey and grey lines are curves of flow discharges monitored in Shizuishan and Bayangaole gauges, respectively; olive and blue lines are curves of suspended sediment loads monitored in Shizuishan and Bayangaole gauges, respectively. 


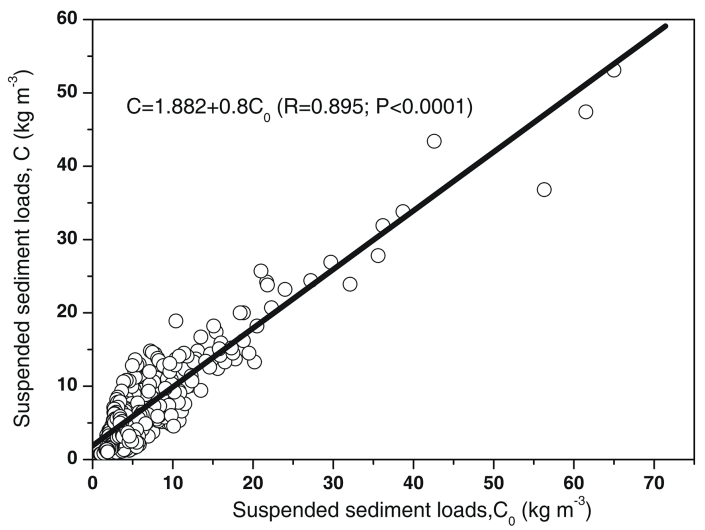

Figure 11. Relation of suspended sediment loads monitored in the Shizuishan gauge $(\mathrm{C} 0)$ and the Bayangaole gauge $(\mathrm{C})$.

braided and meandering rivers, HSF-size segregation interaction is a topic that deserves further consideration and study.

Acknowledgements. This work was supported by the National Basic Research Program of China (no. 2011CB403302) and the One-Hundred Talents Project of CAS "Desert Surface Processes and Mechanisms" and the Natural Science Foundation of China (No. 41171011).

Edited by: T. Glade

Reviewed by: S. J. Wang and another anonymous referee

\section{References}

Church, M.: Bed material transport and the morphology of alluvial river channels, Annu. Rev. Earth Planet. Sci., 34, 325-354, 2006.

Dietrick, W. E. and Smith, J. D.: Influence of the point bar on flow through curved channels, Water Resour. Res., 19, 1173-1192, 1983.

Ferguson, R., Prestegaard, K. L., Ashworth, P. J.: Influence of sand on hydraulics and gravel transport in a braided gravel bed river, Water Resour. Res., 25, 635-643, 1989.

Ferguson, R., Hoey, T., Wathen, S., and Werritty, A.: Field evidence for rapid downstream fining of river gravels through selective transport, Geology, 24, 179-182, 1996.

Frings, R. M.: Downstream fining in large sand-bed rivers, EarthSci. Rev., 87, 39-60, 2008.
Gasparini, N. M., Tucker, G. E., and Bras, R. L.: Downstream fining through selective particle sorting in an equilibrium drainage network, Geology, 27, 1079-1082, 1999.

He, J. L., Guo, J. Y., Xing, E. D., Cui, W., and Li, J. R.: Structure of wind-sand flow and law of dune movement along bank of Yellow River in Ulan Buh desert, T. Chinese Soc. Agr. Eng., 28, 71-77, 2012.

Hoey, T. B. and Ferguson, R.: Numerical simulation of downstream fining by selective transport in gravel bed rivers: Model development and illustration, Water Resour. Res., 30, 2251-2260, 1994.

Lisle, T. E., Nelson, J. M., Pitlick, J., Madej, M. A., and Barkett, B.: Variability of bed mobility in nature, gravel-bed channels and adjustments to sediment load at local and reach scales, Water Resour. Res., 29, 3623-3629, 2000.

Parker, G. and Sutherland, A. J.: Fluvial armor, J. Hydraul. Res., 28, 529-544, 1990.

Pizzuto, J. E.: Downstream fining in a network of gravel-bedded rivers, Water Resour. Res., 31, 753-759, 1995.

Singer, M. B.: Downstream patterns of bed material grain size in a large, lowland alluvial river subject to low sediment supply, Water Resour. Res., 44, W12202, doi:10.1029/2008WR007183, 2008.

Smith, N. D. and Smith, D. G.: William River: An outstanding example of channel widening and braiding caused by bed-load addition, Geology, 12, 78-82, 1984.

Ta, W., Xiao, H., and Dong, Z.: Long-term morphodynamic changes of a desert reach of the Yellow River following upstream large reservoirs' operation, Geomorphology, 97, 249-259, 2008.

Ta, W., Wang, H., and Jia, X.: Downstream fining in contrasting reaches of the sand-bedded Yellow River, Hydrol. Process., 25, 3693-3700, 2011.

Thorne, C. R., Zevenbergen, L. W., Pitlick, J. C., Rais, S., Bradley, J. B., and Julien, P. Y.: Direct measurements of secondary currents in a meandering sand-bed river, Nature, 315, 746-747, 1985.

Wilcock, P. R.: Two-fraction model of initial sediment motion in gravel-bed rivers, Science, 280, 410-412, 1998.

Wilcock, P. R. and Kenworthy, S. T.: A two-fraction model for the transport of sand/gravl mixtures, Water Resour. Res., 38, W1194, doi:10.1029/2001WR000684, 2002.

Wilson, I.: Equilibrium cross-section of meandering and braided rivers, Nature, 241, 393-394, 1973.

Wright, S. and Parker, G.: Modeling downstream fining in sand-bed rivers, I: formation, J. Hydraul. Res., 43, 613-620, 2005.

Wu, B. S. and Li, L. Y.: Delayed response model for bankfull discharge predictions in the Yellow River, Int. J. Sed. Res., 26, 445459, 2011.

Wu, B. S., Maren, D. S., and Li, L. Y.: Predictability of sediment transport in the Yellow River using selected transport formulas, Int. J. Sed. Res., 23, 283-298, 2008. 